\title{
Notas Científicas \\ Casein fractions of ultra high temperature milk with different somatic cell counts
}

\author{
Andrezza Maria Fernandes(1), Fernanda Bovo(1), Thais Santos Moretti(1), Roice Eliana Rosim ${ }^{(1)}$, \\ César Gonçalves de Lima(2) and Carlos Augusto Fernandes de Oliveira(1)
}

(1)Universidade de São Paulo (USP), Faculdade de Zootecnia e Engenharia de Alimentos (FZEA), Departamento de Engenharia de Alimentos, Av. Duque de Caxias Norte, no 225, CEP 13635-900 Pirassununga, SP. E-mail: andrezzaf@hotmail.com, thaismoretti@hotmail.com, fezinhabovo@hotmail.com, roice@usp.br, carlosaf@usp.br (2)USP, FZEA, Departamento de Ciências Básicas. E-mail: cegdlima@usp.br

\begin{abstract}
The objective of this work was to evaluate the effect of somatic cell counts (SCC) in casein fractions of ultra high temperature (UHT) milk. Raw milks were categorized in SCC groups of low (200,000-320,000 cells mL-1), intermediate $\left(380,000-560,000\right.$ cells $\left.\mathrm{mL}^{-1}\right)$ and high cells $\left(600,000-800,000\right.$ cells $\left.\mathrm{mL}^{-1}\right)$. Five replicates of UHT milks within each SCC category were analyzed for casein fractions after 8, 30, 60, 90 and 120 days of storage through high performance liquid chromatography. SCC showed effect only on beta-casein reduction. SCC in raw milk increases the proteolysis of UHT milk, as a consequence of beta-casein degradation.
\end{abstract}

Index terms: SCC, UHT milk, proteolysis, milk quality.

\section{Frações de caseína de leite longa-vida com diferentes contagens de células somáticas}

\begin{abstract}
Resumo - O objetivo deste estudo foi avaliar o efeito da contagem de células somáticas (CCS) do leite nas frações de caseína do leite longa-vida. Os leites crus foram categorizados em grupos de CCS de baixa (200.000-320.000 células $\left.\mathrm{mL}^{-1}\right)$, intermediária $\left(380.000-560.000\right.$ células $\left.\mathrm{mL}^{-1}\right)$ e alta contagem $(600.000$ 800.000 células $\mathrm{mL}^{-1}$ ). Cinco lotes de leite longa-vida, em cada categoria de CCS, foram analisados por cromatografia líquida de alta eficiência quanto às frações de caseína, após 8, 30, 60, 90 e 120 dias de armazenamento. A CCS apresentou efeito somente sobre a beta-caseína. A alta CCS no leite cru aumenta a proteólise do leite longa-vida, como conseqüência da degradação da beta-caseína.
\end{abstract}

Termos para indexação: CCS, leite longa-vida, proteólise, qualidade do leite.

Mastitis is a disease that causes increase in milk somatic cell counts (SCC) and losses to dairy industries, related to changes in milk composition. Main effects of SCC in dairy products include lower yield of cheese (Politis \& Ng-Kwai-Hang, 1988), higher lipolysis in yoghurt (Fernandes et al., 2007), and higher proteolysis in pasteurized milk (Ma et al., 2000). High SCC levels predispose raw milk to hydrolysis of alpha S-casein and beta-casein by proteases, resulting in reduction in these fraction levels (Verdi et al., 1987).

In Brazil, the ultra high temperature (UHT) milk production represents $75.8 \%$ of total fluid milk commercialized (ABLV, 2006). Proteolysis of UHT milk during storage at room temperature is a major factor influencing its shelf life (Vidal-Martins et al., 2005), and might cause undesirable precipitation or gelation (Prado et al., 2006).

The objective of this work was to evaluate the effect of somatic cell counts (SCC) on casein fractions of UHT milk.

This trial was conducted in a commercial dairy plant located in São Paulo State, Brazil, using fifteen batches of UHT milk produced from March 2005 to July 2006. Bulked raw milk was previously tested and presented negative results for antibiotics using Charm SL betalactam test. Heat stability of raw milk samples was evaluated by mixing equal volumes of milk and ethanol solution $78 \%$ (v/v).

Bulked raw milk samples from 250 dairy farms were collected and analyzed for SCC using a somaticell kit, in 
order to select producers for low, intermediate and high SCC. Dairy farms were divided into three groups based upon the bulked milk SCC status: low SCC (200,000-320,000 cells $\left.\mathrm{mL}^{-1}\right)$, intermediate SCC $\left(380,000-560,000\right.$ cells $\left.\mathrm{mL}^{-1}\right)$ and high SCC $(600,000$ 800,000 cells $\left.\mathrm{mL}^{-1}\right)$.

Milk from groups of selected dairy farms were collected separately and transported to the dairy plant immediately after SCC measurement. Milk collected from each SCC category group was bulked until an amount of 8,000-15,000 L was reached. Duplicate samples of $500 \mathrm{~mL}$ of the bulked raw milk were collected from the storage silo before each UHT batch process. Each sample was composed by five individual samples of $100 \mathrm{~mL}$ collected at five intervals of nearly $20 \mathrm{~min}$, during the transference of milk from the silo to the pasteurizer tank. Immediately after collection, samples were submitted to determination of SCC using a somaticell kit to confirm previously estimated levels. These procedures were repeated five times per SCC group, therefore, fifteen batches of UHT milk were produced in the experiment.

Bulked raw milk was previously added with sodium citrate $\left(0.05 \mathrm{~kg} 100 \mathrm{~kg}^{-1}\right.$ milk$)$, pasteurized at $72-75^{\circ} \mathrm{C}$ for $15 \mathrm{~s}$, cooled and stored at $4^{\circ} \mathrm{C}$ until the start of the UHT process in a Tetra Pak UHT system. Psychrotrophic bacteria were analyzed in pasteurized milk (American Public Health Association, 1992) for confirmation of low counts (less than 100 colony forming units per $\mathrm{mL}$ ). Pasteurized milk was pre-heated at $85^{\circ} \mathrm{C}$ and, subsequently, sterilized at $142-145^{\circ} \mathrm{C}$ for $2 \mathrm{~s}$ by direct injection of steam into milk. After condensed water was partially removed, UHT milks were cooled at $70^{\circ} \mathrm{C}$ in a low-pressure chamber $(-0.6 \mathrm{MPa})$, and homogenized (22-25 MPa), then cooled to nearly $20^{\circ} \mathrm{C}$ and aseptically bottled in $1 \mathrm{~L}$ sterile carton boxes. The same conditions were strictly repeated for each of the 15 batches of UHT used in the study. UHT milk samples were stored at room temperature, collected and analyzed after 8, 30, 60, 90 and 120 days of storage.

The concentration of milk casein fractions was determined in raw and UHT stored milk by reversedphase high performance liquid chromatography (HPLC), according to Bobe et al. (1998). Briefly, aliquots containing $500 \mathrm{~mL}$ of milk were frozen at $-20^{\circ} \mathrm{C}$. A solution with $0.1 \mathrm{M}$ BisTris buffer ( $\mathrm{pH}$ 6.8),
$6 \mathrm{M}$ guanidine hydrochloride, $5.37 \mathrm{mM}$ sodium citrate and $19.5 \mathrm{mM}$ dithiothreitol ( $\mathrm{pH}$ 7.0) was added directly to frozen aliquots in a 1:1 ratio (v:v) at room temperature. After thawing, each sample was shaken for $10 \mathrm{~s}$, incubated for 1 hour at room temperature, and centrifuged for $5 \mathrm{~min}$ at $16,000 \mathrm{~g}$ in a micro centrifuge. The fat layer was then removed with a spatula. The remaining soluble sample was diluted $1: 3(\mathrm{v} / \mathrm{v})$ with a solution containing 4.5 M guanidine hydrochloride and solvent $\mathrm{A}$, which consisted of acetonitrile, water, and trifluoroacetic acid in a ratio 100:900:1 (v/v/v; $\mathrm{pH} 2)$. The concentration of milk protein in the final diluted solution was approximately $4 \mathrm{mg} \mathrm{mL}^{-1}$. Final extracts were stored at $7^{\circ} \mathrm{C}$ until the chromatographic analysis was performed, at a maximum of five days after preparation.

Separation and identification of proteins were performed in a HPLC system, equipped with a UV detector at $220 \mathrm{~nm}$ and a Jupiter $\mathrm{C}_{18}$ column ( $4 \mathrm{~mm}, 4.6 \mathrm{X} 150 \mathrm{~mm}$ ). Samples were filtered through a PTFE $0.45 \mathrm{~mm}$ membrane, and $20 \mathrm{~mL}$ solution were injected in the HPLC system. Chromatographic run was performed at room temperature using the following mobile phases: solvent A (acetonitrile:water:trifluoroacetic acid, 100:900:1) and solvent B (acetonitrile:water:trifluoroacetic acid, 900:100:1). The gradient program started with $25 \%$ solvent B, gradually increasing the proportion of solvent $\mathrm{B}$ immediately after sample injection [34\% (4 min), 48\% (11 $\mathrm{min}$ ), 50\% (13 $\mathrm{min}$ ), 10\% (17 $\mathrm{min}$ )] and returning to initial conditions after $2 \mathrm{~min}$. The flow rate was adjusted at $1 \mathrm{~mL} \mathrm{~min}^{-1}$.

The quantification of casein fractions (alpha S1, alpha S2, beta and kappa) in samples was performed by measuring peak areas of samples, and plotting against the calibration curves of each casein fraction. Purified alpha S-, beta- and kappacasein standards were diluted in distilled water, and aliquots were frozen at $-20^{\circ} \mathrm{C}$. Individual casein standards were prepared in the same way as described for milk samples, at the following concentrations: alpha S-casein: $0.5,1,2$ and $4 \mathrm{mg} \mathrm{mL}-1$; beta-casein: $0.375,0.75,1.50 \mathrm{e}$ $3 \mathrm{mg} \mathrm{mL}^{-1}$; kappa-casein: $0.187,0.375,0.75$ and $1.50 \mathrm{mg} \mathrm{mL}^{-1}$. The ratio of alpha S1- to alpha S2-casein was assumed to be $4: 1(\mathrm{w} / \mathrm{w})$.

Results from duplicate analyses of raw and pasteurized milks were submitted to ANOVA, using the 
general linear model procedure of SAS. A split-plot design was utilized to monitor the effects of SCC, storage time, and their interaction on the measured casein fractions after storage. Analysis of variance for the split plot design was carried out using the Proc Mixed of SAS. Significant differences between different treatment levels were determined by Tukey test (Gacula \& Singh, 1984). All statements of significance were based on 5\% level of probability.

The retention times for alpha S1-, alpha S2-, beta- and kappa-casein by HPLC were 10.9, 9.3, 11.4, and $8.3 \mathrm{~min}$, respectively. The casein fractions concentrations in raw and pasteurized milks are presented in Table 1. The alpha S2-casein concentration in raw milk was significantly lower for high SCC group, when compared with the intermediate SCC, although no difference was found between the low SCC group and the others. There were no differences among groups for the other casein fractions in raw and pasteurized milks.

Table 2 presents the means of caseins concentrations in UHT milk for each SCC group during storage. No influence of SCC on alpha S1-, alpha S2- and kappacasein in UHT milk was observed. However, a reduction

Table 1. Effect of somatic cell counts (SCC) on casein fraction content in raw and pasteurized milk ${ }^{(1)}$.

\begin{tabular}{|c|c|c|c|c|}
\hline \multirow[t]{2}{*}{ Fraction $\left(\mathrm{mg} \mathrm{mL}^{-1}\right)$} & \multicolumn{3}{|c|}{$\mathrm{SCC}\left(\mathrm{x} 1,000\right.$ cells $\left.\mathrm{mL}^{-1}\right)$} & \multirow[t]{2}{*}{$\mathrm{SE}$} \\
\hline & $200-320$ & $380-560$ & $600-800$ & \\
\hline & \multicolumn{4}{|c|}{ Raw milk } \\
\hline Alpha S1-casein & 9.98 & 10.26 & 9.19 & 0.47 \\
\hline Alpha S2-casein & $1.26 \mathrm{ab}$ & $1.39 \mathrm{a}$ & $0.98 b$ & 0.10 \\
\hline Beta-casein & 10.82 & 10.33 & 9.43 & 0.47 \\
\hline \multirow{2}{*}{ Kappa-casein } & 3.16 & 3.65 & 3.24 & 0.14 \\
\hline & \multicolumn{4}{|c|}{ Pasteurized milk } \\
\hline Alpha S1-casein & 9.82 & 9.64 & 9.55 & 0.57 \\
\hline Alpha S2-casein & 1.15 & 1.07 & 0.99 & 0.13 \\
\hline Beta-casein & 11.52 & 11.55 & 10.35 & 0.68 \\
\hline Kappa-casein & 3.02 & 3.28 & 3.41 & 0.22 \\
\hline
\end{tabular}

in all casein fraction concentrations was found in UHT milks during storage, except for alpha S2-casein. Also, no interaction effects between SCC and storage time on any casein fraction were observed.

The reductions in casein fractions of UHT milks during storage are associated with the proteolytic activity of heat-resistant enzymes, such as plasmin (Bastian \& Brown, 1996). Proteolysis of UHT milk associated with plasmin, during storage at room temperature, decreases its shelf life and might cause undesirable precipitation or gelation (Topçu et al., 2006).

A significant effect of SCC was observed on betacasein concentration (Table 2), with lower concentrations of this fraction in the higher SCC UHT milk, when compared to the low SCC group. In raw milk, high SCC is associated with hydrolysis of alpha Sand beta-casein by proteases, resulting in a lower concentration of these fractions (Verdi et al., 1987). The proteolysis by those plasmin occurs in the following predominance beta- > alpha S1- > kappa-casein (Grieve \& Kitchen, 1985). In this work, SCC affected betacasein concentrations in UHT milk, an effect that can be primarily attributed to plasmin.

The most important consequence of the changes in casein fractions of UHT milk during storage is the disaggregation of casein micelles, which could lead to milk gelation (Datta \& Deeth, 2001). Besides, enzymatic hydrolysis of casein associated with SCC may lead to important sensory changes in milk, mainly the bitter taste due to peptides release, which were shown to be originated mostly from alpha S1- and beta-casein (Lemieux \& Simard, 1991).

Results of this trial indicate that high SCC in raw milk increases the proteolysis of UHT milk, as a consequence of beta-casein degradation, which may negatively affect the product quality and lead to a lower nutritional value.

Table 2. Effect of somatic cell counts (SCC) on casein fraction content in UHT milk ${ }^{(1)}$.

\begin{tabular}{|c|c|c|c|c|}
\hline \multirow{2}{*}{$\begin{array}{c}\mathrm{SCC} \\
\left(\mathrm{x} 1,000 \text { cells } \mathrm{mL}^{-1}\right)\end{array}$} & \multicolumn{4}{|c|}{ Casein fractions $\left(\mathrm{mg} \mathrm{mL}^{-1}\right)$} \\
\hline & Alpha S1-casein & Alpha S2-casein & Beta-casein & Kappa-casein \\
\hline $200-320$ & 8.70 & 1.67 & $10.04 \mathrm{a}$ & 2.96 \\
\hline $380-560$ & 8.70 & 1.84 & $9.60 \mathrm{ab}$ & 3.58 \\
\hline $600-800$ & 8.04 & 1.41 & $7.92 b$ & 3.51 \\
\hline Standard error & 0.60 & 0.14 & 0.49 & 0.35 \\
\hline $\begin{array}{l}\text { SCC } \\
\text { Time }\end{array}$ & $\mathrm{y}=-0.03 \mathrm{x}+10.327\left(\mathrm{R}^{2}=0,96\right)$ & - & $\begin{array}{l}\text { ar regression equations } \\
\mathrm{y}=-1.064 \mathrm{x}+11.316\left(\mathrm{R}^{2}=0,90\right) \\
\mathrm{y}=-0.315 \mathrm{x}+11.130\left(\mathrm{R}^{2}=0,98\right)\end{array}$ & $\mathrm{y}=-0.006 \mathrm{x}+3.721\left(\mathrm{R}^{2}=0,84\right)$ \\
\hline
\end{tabular}

${ }^{(1)}$ Means followed by the same letters do not differ by Tukey test, at $5 \%$ of probability. 


\section{Acknowledgements}

To Fundação de Amparo à Pesquisa do Estado de São Paulo (Brazil), for financial support.

\section{References}

ABLV. Associação Brasileira de Leite Longa-vida. Avaiable at: <http:/ /www.ablv.org.br>. Acessed on: 15 Oct. 2006.

AMERICAN PUBLIC HEALTH ASSOCIATION. Standard methods for the examination of dairy products. $16^{\text {th }} \mathrm{ed}$. Washington, DC, USA: American Public Health Association, 1992.

BASTIAN, E.D.; BROWN, R.J. Plasmin in milk and dairy products: an update. International Dairy Journal, v.6, p.435-457, 1996.

BOBE, G.; BEITZ, D.C.; FREEMAN, A.E.; LINDBERG, G.L. Separation and quantification of bovine milk proteins by reversedphase high performance liquid chromatography. Journal of Agricultural and Food Chemistry, v.46, p.458-463, 1998.

DATTA, N.; DEETH, H.C. Age gelation of UHT milk - a review. Food and Bioproducts Processing, v.79, p.197-210, 2001.

FERNANDES, A.M.; OLIVEIRA, C.A.F.; LIMA, C.G. Effects of somatic cell counts in milk on physical and chemical characteristics of yoghurt. International Dairy Journal, v.17, p.111-115, 2007.

GACULA, J.R.; SINGH, J. Statistical methods in food and consumer research. Orlando: Academic Press., 1984, 505p.

GRIEVE, P.A.; KITCHEN, B.J. Proteolysis in milk: the significance of proteinases originating from milk leucocytes and a comparison of the action of leukocyte, bacterial and natural milk proteinases on casein. Journal of Dairy Research, v.52, p.101-112, 1985.

LEMIEUX, L.; SIMARD, R.E. Bitter flavour in dairy products. 1. A review of the factors likely to influence its development, mainly in cheese manufacture. International Dairy Journal, v.71, p.599636, 1991.

MA, Y.; RYAN, C.; BARBANO, D.M.; GALTON, D.M.; RUDAN, M.A.; BOOR, K.J. Effects of somatic cell count on quality and shelf-life of pasteurized fluid milk. Journal of Dairy Science, v.83, p.264-274, 2000.

POLITIS, I.; NG-KWAI-HANG, K.F. Effects of somatic cell counts and milk composition on cheese composition and cheese making efficiency. Journal of Dairy Science, v.71, p.1711-1719, 1988.

PRADO, B.M.; SOMBERS, S.E.; ISMAIL, B.; HAYES, K.D. Effect of heat treatment on the activity of inhibitors of plasmin and plasminogen activators in milk. International Dairy Journal, v.16, p.593-599, 2006.

TOPÇU, A.; NUMANOGLU, E.; SALDAMLI, I. Proteolysis and storage stability of UHT milk produced in Turkey. International Dairy Journal, v.16, p.633-638, 2006.

VERDI, R.J.; BARBANO, D.M.; DELLAVALLE, M.E.; SENIK, G.F. Variability in true protein, casein, nonprotein nitrogen, and proteolysis in high and low somatic cell milks. Journal of Dairy Science,v.70, p.230-242, 1987.

VIDAL-MARTINS, A.M.C.; SALOTTI, B.M.; ROSSI JUNIOR, O.D.; PENNA, A.L.B. Evolução do índice proteolítico e do comportamento reológico durante a vida de prateleira de leite UAT/UHT. Ciência e Tecnologia de Alimentos, v.25, p.698-704, 2005. 